\title{
crianças no apogeu do tráfico interno de escravos (piracicaba, província de são paulo, 1874-1880)
}

\section{children in the heyday of the internal slave trade (piracicaba, province of são paulo, 1874-1880)}

\author{
José Flávio Motta $\star \star$ \\ Faculdade de Economia, Administração e Contabilidade, Universidade de São Paulo, São Paulo, \\ Brasil
}

\section{RESUMO}

Analisamos transações envolvendo crianças escravas ou ingênuas com 12 ou menos anos de idade, identificadas em Piracicaba (SP), no período 1874-1880, anos de apogeu do tráfico interno de cativos. Durante esse intervalo temporal, era proibida a separação pela venda de cônjuges escravos, bem como entre pais e filhos menores. Estudamos as vendas de crianças desacompanhadas de
Abstract

In this work we study transactions involving slave children and ingênuos children (free children born to slave mothers) up to 12 years of age identified in Piracicaba (São Paulo province) in the years 1874-1880, the peak of the internal slave trade. Transactions that separated married slave couples or slave parents from their children below the age of legal majority were forbidden in this period.

* Neste artigo lançamos mão de fontes primárias manuscritas levantadas e coletadas na vigência de uma bolsa de produtividade em pesquisa concedida pelo $\mathrm{CNPq}$ Conselho Nacional de Desenvolvimento Científico e Tecnológico, que gerou, como principal produto, nossa tese de livre-docência, defendida em 2010 e posteriormente publicada com auxílio da FAPESP (Motta, 2012a). Uma primeira versão do texto foi apresentada no 7ํ ENCONTRO ESCRAVIDÃO E LIBERDADE NO BRASIL MERIDIONAL, realizado em Curitiba (PR), de 13 a 16 de maio de 2015, e também no XI CONGRESSO BRASILEIRO DE HISTÓRIA ECONÔMICA e 12a CONFERÊNCIA INTERNACIONAL DE HISTÓRIA DE EMPRESAS, realizados em Vitória (ES), de 14 a 16 de setembro de 2015. O autor agradece os comentários recebidos em Curitiba e em Vitória; agradece, outrossim, as sugestões feitas pelos avaliadores da revista História Econômica \& História de Empresas.

Submetido: 27 de outubro de 2015; aceito: 19 de janeiro de 2016.

$\star \star$ Professor associado 3, livre-docente da FEA-USP. Professor do Programa de Pós-Graduação em História Econômica da FFLCH-USP. Membro do Hermes \& Clio - Grupo de Estudos e Pesquisa em História Econômica da FEA-USP e do NEHD - Núcleo de Estudos em História Demográfica da FEA-USP. E-mail: jflaviom@usp.br 
familiares, isoladas ou não, e as vendas de crianças acompanhadas de familiares, presentes ou não outros escravos. Consideramos igualmente a presença de ingênuos, os quais acompanhavam suas mães cativas. Nossas fontes documentais são escrituras de transações envolvendo escravos, registradas em livros notariais destinados a esse fim e manuscritas por tabeliães do município escolhido.

Palavras-chave: Tráfico interno de escravos. Crianças escravas. Ingênuos. Famílias escravas. Piracicaba.
We study the sales of children not accompanied of relatives, isolated or in groups, as well as the sales of children accompanied of relatives, whether or not along with other slaves. The presence of ingênuos children, who accompanied their slave mothers, was also taken into account. Our documentary sources are deeds involving slaves, handwritten in special registries by notaries from the selected locality.

Keywords: Internal slave trade. Slave children. Ingênuos. Slave families. Piracicaba.

\section{Introdução}

No último quarto do século XVIII, a localidade objeto de nossa atenção neste artigo integrou-se ao desenvolvimento paulista assentado na lavoura canavieira ${ }^{1}$. Caio Prado Júnior, por exemplo, em seu Formação do Brasil contemporâneo: colônia, escreveu:

No conjunto, a população paulista ascende de 116.975 habitantes em 1777 para 192.729 em 1805. Tal crescimento se verifica particularmente na área central da capitania, entre os rios Mogi, Piracicaba eTietê, grosseiramente o quadrilátero compreendido entre as vilas de Mogi Guaçu, Jundiaí, Porto Feliz e Piracicaba (esta ainda simples freguesia). É a cana-de-açúcar que faz a prosperidade desta região. (Prado Jr., 2011, p. 84)

E esse avanço da cultura de cana e da produção de açúcar a ela vinculada será, de modo inequívoco, elemento importante na definição dos contornos assumidos pela posterior introdução da cafeicultura na região. No que respeita especificamente a Piracicaba, Maria Thereza Schorer Petrone afirmou que, em 1816, “a produção de açúcar constituía aí a

1 Referir-nos-emos à dita localidade como Piracicaba ao longo de todo o texto. Não obstante, cabe explicitar a seguinte ressalva: em 1769 foi criada a Freguesia de Santo Antonio de Piracicaba, elevada à "categoria de Vila em 1822, sendo substituído o seu primitivo nome pelo de Constituição, e foi elevada a cidade em 1856” (Luné; Fonseca, 1985, p. 462). Tão somente na segunda metade da década de 1870, o nome do município foi alterado para Piracicaba. 
principal atividade da população”, papel destacado que se manteve até meados do século XIX, quando a cafeicultura, contudo, já atraía inúmeros agricultores em outras áreas da Província de São Paulo. É ainda a mesma autora quem identifica essa "resistência" piracicabana ao café:

A obsessão do café não atingiu a região, pelo menos até essa data [1854]. O cultivo da cana em Piracicaba, como em Itu, continuou progredindo, não sendo afetado pela penetração do café, como aconteceu em Campinas. Itu e Piracicaba, os vales do Tietê e do Piracicaba, portanto, eram, em meados do século passado [XIX], os redutos da cana-de-açúcar. (Petrone, 1968, p. 49)

Todavia, não seria fácil resistir a um conquistador comparável a Átila! ${ }^{2}$ E, de fato, datados de princípios da década de 1860, encontramos os comentários seguintes acerca da cidade analisada, constantes do relato feito por Augusto Emílio Zaluar sobre sua viagem, a partir de fins de 1859, à província paulista:

A sua produção de café e açúcar regula, termo médio, em cento e cinquenta mil arrobas. É preciso notar que a cultura do café é aqui de data muito recente, pois ainda há muito pouco tempo os Piracicabanos se entregavam exclusivamente ao cultivo da cana, que com esta inovação tem consideravelmente diminuído. (Zaluar, 1975, p. 151, grifo nosso)

Ao fim e ao cabo, a "rendição" de Piracicaba à cafeicultura, ainda que não absoluta, é corroborada com base em um relatório produzido pelas autoridades do município em meados dos anos de 1860, do qual se vale Maria Celestina Teixeira Mendes Torres em interessante ensaio sobre o Comendador Luiz Antonio de Souza Barros ${ }^{3}$ :

2 É de Monteiro Lobato o trecho seguinte, extraído do conto Cidades mortas, escrito em 1906 e versando sobre o chamado "Norte" Paulista: "Umas tantas cidades moribundas arrastam um viver decrépito. [...] No campo não é menor a desolação. Léguas a fio se sucedem de morraria áspera, onde reinam soberanos a saúva e seus aliados, o sapé e a samambaia. Por ela passou o café, como um Átila” (Lobato, 1986, p. 3-6).

3 Filho do Brigadeiro Luiz Antonio, o Comendador Souza Barros e alguns de seus irmãos mantiveram vínculos estreitos com o município de Piracicaba. Seu inventário, de 1887, foi um dos analisados por Zélia Maria Cardoso de Mello. Essa autora escreveu: “Capitalista', 'proprietário', fazendeiro, foi um dos maiores acionistas 
O Relatório Municipal de 1866 evidencia claramente os novos aspectos da economia piracicabana, reflexo da economia da Província de São Paulo: a) diminuição da produção açucareira; b) expansão da lavoura cafeeira; c) retalhamento da propriedade rural; d) maior número de trabalhadores livres; e) maior diversificação de lavouras - pequenas lavouras de algodão e de "gêneros alimentares".

$[\ldots]$

No município de Piracicaba é manifesta a decadência da produção açucareira. Em 1857 o município produzira 100.000 arrobas de açúcar e 80.000 de café; em 1866, a produção de açúcar baixa para 39.400 e a do café sobe para 112.830 arrobas. (Torres, 1966, p. 35-36)

Assim, pois, a década de 1870, em especial seus derradeiros dois terços, quando o Império do Brasil vivenciou o auge do comércio interno de escravos, sobretudo em sua vertente interprovincial, encontrou Piracicaba em grande medida dedicada à cafeicultura ${ }^{4}$. Em seus Apontamentos publicados originalmente em fins daquele decênio, afirmou Manuel Eufrásio de Azevedo Marques sobre o aludido município:

A sua única indústria é a lavoura, sobressaindo a do café e a da cana, de que conta muitas e importantes fazendas. [...] Também produz com abundância e facilidade algodão e toda a sorte de gêneros alimentícios. A

na formação da Companhia Paulista. [...] Entre seus bens, além de casas em São Paulo, arrolavam-se nove fazendas em Campinas, Botucatu, Piracicaba, São Carlos do Pinhal, que somavam quase 1.500 alqueires com plantações de café (588.000 pés) e cana, máquinas de secar e beneficiar café, engenho e máquinas a vapor. Era proprietário de grande número de escravos e encontrava-se entre os fazendeiros [...] que participaram das colônias de parceria. [...] Suas receitas advinham de aluguéis, vendas de café e dividendos de ações” (Mello, 1985, p. 132-133).

4 Sobre a intensidade diferenciada do tráfico interno de cativos no Brasil, no decurso da segunda metade do Oitocentos, ver, por exemplo, Gorender (1985, p. 326-328). Ademais, à periodização proposta por Gorender, convém agregar as modificações sugeridas em Motta (2012a, p. 81, 91). Especificamente sobre o auge nos anos de 1870, escreveu, por exemplo, Peter Eisenberg: "O tráfico interprovincial chegou ao auge na década de 1870 em virtude das severas secas nordestinas que forçaram a liquidação dos ativos fixos, como os escravos. O total de escravos embarcados para o sul, após 1876, foi tão elevado que as províncias compradoras - Rio de Janeiro, São Paulo e Minas Gerais - impuseram elevados tributos à importação de escravos, em 1880 e 1881. [...] Os tributos acabaram com o tráfico interprovincial de escravos" (Eisenberg, 1977, p. 175-177). 
exportação do município regula, termo médio, 130.000 arrobas de café, 50.000 de açúcar e 20.000 de algodão. (Marques, 1953, v. 1, p. 198) ${ }^{5}$

De acordo com o primeiro "Recenseamento geral do Império", de 1872, realizado na Província de São Paulo aos 30 de janeiro de 1874, a população piracicabana somava 18.980 pessoas. Desse total, 13.566 $(71,5 \%)$ eram livres e $5.414(28,5 \%)$, escravos ${ }^{6}$. No contingente de cativos, a maioria era do sexo masculino: 3.112 (57,5\%). A razão de sexo da população escrava, portanto, correspondia a 135,2 homens para cada grupo de 100 mulheres, indicador que, no caso da população livre, refletia um equilíbrio muito maior entre os sexos $(103,5)$.

\section{O tráfico de crianças em Piracicaba de 1874 a 1880}

No intervalo de sete anos por nós contemplado neste artigo foram registradas em Piracicaba 203 escrituras de transações envolvendo 557 escravos. Trocaram de mãos, portanto, em média, cerca de três cativos em cada um desses negócios. Foram 496 pessoas com 13 ou mais anos de idade e 61 crianças com 12 ou menos anos. Ademais, em várias escrituras, mulheres foram negociadas "acompanhadas" por crianças ingênuas, as quais somaram $59^{7}$. No total, entre escravos e ingênuos, 616 pessoas. Na Tabela 1 fornecemos a distribuição desses três subconjuntos pelos distintos anos considerados ${ }^{8}$.

5 A produção cafeeira de Piracicaba alçar-se-ia, mencionemos, a 300.000 arrobas em 1886 (cf. Milliet, 1939, p. 43).

6 Recorremos, para os dados do "Recenseamento" de 1872, às tabulações realizadas pelo Núcleo de Estudos em População da Universidade Estadual de Campinas NEPO-UNICAMP (cf. Bassanezi, 1998). O número de cativos matriculados até 30 de setembro de 1872 no município em tela foi igual a 5.339 , portanto menor do que o recenseado (cf. Luné; Fonseca, 1985, p. 172). Ressalvemos que essa última cifra é, no Almanak de 1873, vinculada à Estação Fiscal de Constituição e, ao que parece, inclui a agência de Santa Bárbara. Se computarmos igualmente os escravos de Santa Bárbara em 1874, o total de cativos recenseados aumenta de 5.414 para 5.627 .

7 Como sabido, "ingênuos" eram os filhos de mães escravas nascidos na vigência da Lei do Ventre Livre.

8 Se computadas também as crianças ingênuas, a média de pessoas transacionadas por escritura elevar-se-ia de 2,74 para 3,03. 
Optamos pela utilização da faixa etária de até 12 anos para caracterizar o contingente de crianças como uma decorrência direta da Lei n. 2.040 , de 28 de setembro de 1871. Em vigência por todo o período por nós analisado, a Lei do Ventre Livre dispunha em um dos parágrafos de seu Artigo 4ㅇ. " $\int 77^{\circ}$. Em qualquer caso de alienação ou transmissão de escravos é proibido, sob pena de nulidade, separar os cônjuges, e os filhos menores de 12 anos, do pai ou mãe" (Coleção de leis do Império do Brasil) ${ }^{9}$.

Além disso, convém registrar o fato de que, até 1880, limite superior de nosso recorte temporal, todos os casos de ingênuos identificados nas escrituras estarão inseridos, necessariamente, na faixa etária em questão.

Tabela 1 - Escravos transacionados segundo duas faixas etárias e ano do registro. Ingênuos mencionados nas escrituras segundo ano do registro. (Piracicaba, 1874-1880)

\begin{tabular}{c|c|c|c|c|c}
\hline Anos & $\begin{array}{c}\text { Cativos com 13 } \\
\text { OU MaIS ANOS }\end{array}$ & $\begin{array}{c}\text { Cativos COM 12 } \\
\text { OU MENOS ANOS }\end{array}$ & $\begin{array}{c}\text { CrianÇAS } \\
\text { INGÊNUAS }\end{array}$ & Totais & $\begin{array}{c}\text { CrianÇAS ESCRAVAS } \\
\text { + INGÊNUAS (\%) }\end{array}$ \\
\hline 1874 & 62 & 7 & 4 & 73 & 15,1 \\
1875 & 99 & 21 & 5 & 125 & 20,8 \\
1876 & 35 & 6 & 2 & 43 & 18,6 \\
1877 & 30 & 2 & 1 & 33 & 9,1 \\
1878 & 112 & 12 & 18 & 142 & 21,1 \\
1879 & 106 & 10 & 21 & 137 & 22,6 \\
1880 & 52 & 3 & 8 & 63 & 17,5 \\
Totais & 496 & 61 & 59 & 616 & 19,5 \\
\hline
\end{tabular}

Fonte: Escrituras de transações envolvendo escravos.

A bem da verdade, essas crianças nascidas após a promulgação da Lei n.2.040 não deveriam ser transacionadas, uma vez que não eram escravas. Mas também não poderiam ser separadas de suas mães. De fato, o que se fazia era transferir aos compradores daquelas mulheres o direito de usufruir dos serviços de seus filhos ingênuos ${ }^{10}$.

9 É oportuno lembrarmos que a dita proibição constara, anteriormente, do Artigo $2^{\circ}$ do Decreto n. 1.695, de 15 de setembro de 1869, todavia estabelecendo um recorte etário diferente, permitindo a separação apenas de filhos maiores de 15 anos (cf. Coleção de leis do Império do Brasil).

10 Como disposto no $\int 5^{\circ}$ do Artigo $1^{\circ}$ da Lei n. 2.040: "No caso de alienação da mulher escrava, seus filhos livres, menores de 12 anos, a acompanharão, ficando o novo senhor da mesma escrava sub-rogado nos direitos e obrigações do antecessor" (Coleção de leis do Império do Brasil). 
Tomemos, como exemplo desse procedimento, o caso de uma escritura datada aos 15 de maio de 1879 e registrada na localidade também paulista de Casa Branca.Tratou-se da venda de Margarida, preta, solteira, de 19 anos de idade. Foi um negócio interprovincial, pois o vendedor, Pedro Crescêncio do Lago, era morador em Campestre, na Província de Minas Gerais. Margarida era natural de Campestre e fora matriculada em Caldas, registro posteriormente averbado em Pouso Alegre, sempre na província mineira. O comprador, Francisco de Araújo Govêa, residia em Casa Branca, com o que a cativa seria deslocada para o Oeste Paulista. Não obstante, por ser uma jovem mãe solteira, cujos rebentos nasceram na vigência da Lei de setembro de 1871, a venda de Margarida teve de explicitar a transferência dos serviços de seus pequenos, Clara e José, que necessariamente a acompanhariam. Dessa forma, do documento fez-se constar o seguinte:

[...] Disse mais o outorgante vendedor que tendo a escrava vendida dois filhos ingênuos de nomes Clara, parda, matriculada na mesma Coletoria da Cidade de Caldas Altas [...] em [...] 1874, e José, cor preta, matriculado na mesma Coletoria, transfere na pessoa do outorgado comprador o direito que tem nos serviços dos referidos ingênuos, independente de remuneração pecuniária, visto que pouca despesa há feito com a criação dos mesmos que ainda são mui novos, e se compromete a não reclamar nada no futuro, sob qualquer pretexto. Pelo outorgado comprador me foi dito que aceita a presente escritura [...] e se dá por empossado da compra que fez e das pessoas dos ingênuos.

No período 1874-1880 como um todo, o conjunto formado pelas crianças escravas com 12 ou menos anos, somadas aos ingênuos, correspondeu a cerca de um quinto $(19,5 \%)$ do total das pessoas computadas na Tabela 1. Participação que oscilou de um mínimo de 9,1\% em 1877 a um máximo de $22,6 \%$ em 1879 . E, como esperado, com o passar dos anos os nascidos após a Lei do Ventre Livre foram se tornando cada vez mais importantes. Na Tabela 2 concentramos nossa atenção nas 61 crianças escravas (terceira coluna da Tabela 1). Nossa intenção é situá-las com relação às demais pessoas objeto dos negócios descritos nas escrituras. 
Tabela 2 - Escravos com 12 ou menos anos transacionados segundo presença ou não de outros cativos (familiares ou não) e de acordo com o ano do registro. (Piracicaba, 1874-1880)

\begin{tabular}{c|c|c|c|c|c}
\hline ANOS & $\begin{array}{c}\text { CRIANCAS } \\
\text { ESCRAVAS } \\
\text { ISOLADAS }\end{array}$ & $\begin{array}{c}\text { APENAS NÃO } \\
\text { FAMILIARES } \\
\text { PRESENTES }\end{array}$ & $\begin{array}{c}\text { ApENAS } \\
\text { FAMILIARES } \\
\text { PRESENTES }\end{array}$ & $\begin{array}{c}\text { FAMILIARES E } \\
\text { NÃO FAMILIARES } \\
\text { PRESENTES }\end{array}$ & TOtAIS \\
\hline 1874 & - & 1 & 4 & 2 & 7 \\
1875 & - & 10 & 7 & 4 & 21 \\
1876 & - & - & 5 & 1 & 6 \\
1877 & 1 & - & - & 8 & 12 \\
1878 & - & 1 & 3 & 7 & 10 \\
1879 & - & 1 & 2 & 2 & 3 \\
1880 & - & 1 & - & 25 & 61 \\
\hline
\end{tabular}

Fonte: Escrituras de transações envolvendo escravos.

\subsection{Vendas de crianças desacompanhadas de familiares, isoladas ou não}

Tendo em vista a vigência da lei de libertação dos nascituros, poder-se-ia esperar que fossem poucos os cativos com 12 ou menos anos de idade transacionados desacompanhados de seus pais e/ou mães, especialmente de suas mães. Identificamos 15 casos em Piracicaba nos sete anos estudados, cerca de um quarto do contingente negociado naquela faixa etária. Em apenas um deles, a criança era o único bem negociado (segunda coluna da Tabela 2).

Em 1ำ de dezembro de 1877, Dona Anna Joaquina, viúva de Emílio Gomes da Silva, vendeu sua escrava Sebastiana, de 11 anos, por Rs $700 \$ 000^{11}$. Dona Anna residia em Piracicaba, ao passo que o comprador, João Baptista de Oliveira, morava no vizinho município de Limeira. Sebastiana, preta, era natural da Província de São Paulo e havia sido matriculada em Piracicaba. Um terceiro assinou o documento "a rogo" da vendedora, por ela não saber escrever. Quanto à proibição legal in-

11 O livro notarial que continha o registro dessa escritura teve seu "Termo de abertura" assinado pelo Juiz Municipal em 14 de dezembro de 1874, e sua finalidade explícita era o "lançamento de escrituras de vendas de escravos". Notamos que o registro anterior ao referente a Sebastiana fora feito vários meses antes (em julho de 1877) da venda concretizada pela viúva. Esse hiato temporal, para o qual preferimos não avançar nenhuma tentativa de explicação, subjaz ao número relativamente pequeno de pessoas comercializadas em 1877, como podemos observar na Tabela 1. 
cidente sobre a venda de uma criança da idade de Sebastiana, a justificativa fez-se igualmente presente do manuscrito. Assim, esclareceu o Tabelião, "a vendedora declara que a cativa vendida é filha de Antonia, hoje liberta". Todavia, não sabemos quando Antonia foi libertada nem se ela mantinha (ou se lhe era permitido manter) em 1877 algum contato com Sebastiana. Também desconhecemos se a venda da menina para o morador da vizinha Limeira traria implicações em termos das relações entre mãe e filha, seja acarretando seu distanciamento, seja promovendo uma reaproximação.

Casos como esse, ainda que não muito frequentes, não devem causar estranheza ao serem encontrados. Por exemplo, em trabalho anterior, fizemos menção à venda, registrada em Areias, aos 25 de agosto de 1880, de Luis, garoto de 9 anos de idade, natural da Província da Paraíba e descrito, tal como Sebastiana, como "filho de mãe liberta". Luis havia sido matriculado em Pombal, naquela mesma província. Foi vendido juntamente com Pedro, rapaz de 13 anos de idade, natural do Rio de Janeiro e matriculado no município fluminense de Angra dos Reis. Os dois jovens possivelmente haviam sido trazidos para o território de São Paulo antes dessa venda de 1880. De fato, seu vendedor era o Alferes Cláudio Louzada, morador na paulista São Simão, representado perante o Tabelião em Areias por um procurador. O comprador, José Joaquim de Oliveira Moraes, era morador do município vale-paraibano. É oportuno retomar algo de nossas reflexões acerca dessa venda:

A comercialização desse menino suscita questionamentos para os quais não temos respostas, embora permitam levantar algumas conjecturas. Haveria quem se interessasse em averiguar a veracidade dessa informação acerca do status social da mãe que, ao fim e ao cabo, tornou legítima a venda? A conformidade com o espírito da lei não exigiria que se fizessem constar da escritura informações mais detalhadas sobre essa mulher liberta? Em verdade, a impressão passada pelo documento é que a declarada liberdade da mãe "funcionou" como se fora um "atestado de orfandade" de Luis. (Motta, 2012b, p. 20)

É oportuno aqui observar que mesmo a presença de uma declaração de orfandade poderia, é claro, não ser verdadeira. Warren Dean, por exemplo, para a localidade paulista por ele estudada, sugeriu ser provável uma elevada frequência de declarações falsas nessa documentação notarial: 
As vendas de escravos registradas em Rio Claro a partir de 1872 consistiam na maior parte - é interessante observar - de meninos de 10 a 15 anos. Raramente eles eram acompanhados dos pais, sendo declarados quase sempre, é provável, falsamente - de mãe desconhecida ou morta. (Dean, 1977, p. 69, grifo nosso)

Para 14 das "nossas" crianças, listadas no Quadro 1, apesar de negociadas com outros escravos, não foi possível identificar quaisquer relações familiares com pessoas pertencentes aos respectivos lotes em que se inseriam. Esses grupos de escravos variaram de um mínimo de dois ao máximo de 47. Na grande maioria dessas situações (13 das 14), de modo distinto ao verificado na venda de Sebastiana, não há, ao que parece, nenhuma preocupação do Tabelião e/ou dos contratantes com a necessidade de esclarecer a aparente desobediência ao disposto no $\int 7$ do Artigo $4^{\circ}$ da Lei de 28 de setembro de 1871.

Assim, entre os dias 9 e 13 de setembro de 1875, foram registradas várias escrituras nas quais quem vendia era José Ferreira de Figueiredo. Mas ele era proprietário de poucos dentre os escravos vendidos. $\mathrm{Na}$ grande maioria dos casos, Figueiredo atuou como procurador. No dia 9 , por exemplo, foi lançada a escritura de venda de dois cativos, Caetano e Valério, comprados por Francisco Jeremias Ferraz, morador em Rio Claro, município próximo de Piracicaba.Valério tinha 11 anos de idade, sendo portanto uma das 14 crianças computadas no Quadro 1 e na terceira coluna da Tabela 2. O menino era natural da Província da Bahia, onde fora matriculado em Caetité, localidade na qual residia seu proprietário anterior, Bento José Alves. Caetano, por seu turno, um jovem de 24 anos, era natural do Rio de Janeiro e fora matriculado em Parati, onde também morava seu antigo senhor, o tenente-coronel Manoel José de Souza.

Outras quatro dessas 14 crianças integraram um conjunto de 22 cativos comercializado pelo mesmo José Ferreira de Figueiredo no dia 13 de setembro de 1875. O lote foi comprado pelo Comendador Francisco José da Conceição, residente em Piracicaba, por 26 contos de réis. Um dos pequenos era propriedade de Figueiredo: Francisco, preto, de 12 anos de idade, natural da Província de Minas Gerais e lá matriculado, em Rio Pardo. Por seu turno, Januário, Pedro e Sebastião, todos pretos, naturais da Província da Bahia e com 9 anos, pertenciam a três distintos 
proprietários, respectivamente, José da Costa Santos, Serapião Francisco de Campos e Leolino Xavier Cotrim, os três moradores naquela mesma província.

\begin{tabular}{|c|c|c|c|c|}
\hline $\begin{array}{l}\text { NOME DA } \\
\text { CRIANÇA }\end{array}$ & IDADE & $\begin{array}{l}\text { Naturalidade } \\
\text { (PROVÍNCIA) }\end{array}$ & $\begin{array}{l}\text { DATA DA } \\
\text { ESCRITURA }\end{array}$ & $\begin{array}{c}\text { NÚMERO DE ESCRAVOS } \\
\text { NEGOCIADOS }\end{array}$ \\
\hline Manoel & 12 & SC & $20 / 7 / 1874$ & 6 \\
\hline Lauro & 12 & SP & $7 / 1 / 1875$ & 21 \\
\hline João & 11 & SP & $7 / 1 / 1875$ & 21 \\
\hline Valério & 11 & BA & $9 / 9 / 1875$ & 2 \\
\hline Januário & 9 & BA & $13 / 9 / 1875$ & 22 \\
\hline Pedro & 9 & BA & $13 / 9 / 1875$ & 22 \\
\hline Francisco & 12 & $\mathrm{MG}$ & $13 / 9 / 1875$ & 22 \\
\hline Sebastião & 9 & BA & $13 / 9 / 1875$ & 22 \\
\hline José & 12 & MG & $16 / 10 / 1875$ & 4 \\
\hline Olegário & 10 & $\mathrm{MG}$ & $16 / 10 / 1875$ & 4 \\
\hline Isidoro & 12 & MG & $16 / 10 / 1875$ & 4 \\
\hline Messias & 12 & SP & $31 / 12 / 1878$ & 25 \\
\hline Vicente & 11 & Não consta & 17/12/1879 & 47 \\
\hline Simão & 12 & PE & $5 / 10 / 1880$ & 8 \\
\hline
\end{tabular}

Fonte: Escrituras de transações envolvendo escravos.

Desse grupo de 22 escravos, transacionados com a intermediação do procurador Figueiredo, Serapião vendeu apenas Pedro, matriculado em Monte Alto (BA). José da Costa Santos, além de Januário, vendeu também Manoel, rapaz de 13 anos. E Leolino Cotrim, além de Sebastião, vendeu também Margarida, mulher solteira com 28 anos de idade. Não há nenhuma indicação na escritura acerca da existência de relações consanguíneas entre Januário e Manoel, ou entre Margarida e Sebastião ${ }^{12}$. Teria havido um descuido do Tabelião, do procurador, dos antigos proprietários, quiçá de todos eles? É possível. Todavia, no mesmo negócio tratado com o Comendador piracicabano, um outro escravista, Donato Pereira do Nascimento, morador na citada Monte Alto da Bahia, vendeu Ângela, solteira de 25 anos, e Jesuína, de 5, e elas foram descritas como mãe e filha ${ }^{13}$.

\footnotetext{
12 Os quatro haviam sido matriculados em Caetité (BA).

13 Jesuína está, pois, computada na quinta coluna da Tabela 2.
} 
Talvez seja viável conjecturarmos que a falta de justificativa para o aparente descumprimento da Lei do Ventre Livre, e mesmo a concentração, no início do período contemplado, desses casos nos quais a justificativa seria necessária, porém não foi apresentada, tenha a ver com o então relativamente limitado tempo de vigência da lei. Afinal, como sabido, foi rubricado pelo Imperador aos 13 de novembro de 1872 o Decreto n. 5.135, em cujo caput lemos: "Aprova o regulamento geral para a execução da lei nº.2.040 de 28 de setembro de 1871”. Com isso, frisemos, não estamos sugerindo a inexistência de efeitos da lei naqueles primeiros anos; a maioria absoluta de meninos listados no Quadro 1 indicia seu impacto.

Convém lembrarmos que, conforme escreveu Warren Dean na citação por nós transcrita alguns parágrafos acima, meninos de 10 a 15 anos comporiam a maior parte das vendas de cativos registradas em Rio Claro, a partir de 1872. As fontes indicadas para fundamentar tal afirmação são os livros de vendas de escravos, similares aos que embasam nossas reflexões; não obstante, e em especial se encarada como um padrão nacional ou mesmo regional, essa proporção que ele menciona parece-nos algo exagerada. Por exemplo, em Piracicaba, em 1875, dos 120 escravos transacionados nas escrituras que compulsamos, os rapazes de 10 a 15 anos somaram 19, portanto menos de um sexto.

Metade desses 14 meninos elencados no Quadro 1 foram negociados no tráfico interprovincial, quatro deles vendidos por escravistas residentes em províncias do Nordeste do Império ${ }^{14}$. Dessa forma, com a libertação dos nascituros, enquanto as meninas perderam seu atrativo como futuras "produtoras" de novos escravos, os moleques passaram a ser os cativos com as maiores possibilidades em termos de duração do cativeiro e, por conseguinte, valiosos a ponto, eventualmente, de compensarem o risco

14 Foi o informe sobre o local de moradia dos contratantes das escrituras compulsadas que fundamentou a segmentação das transações em "locais" (residência nas próprias localidades onde se fizeram os registros ou em seus termos), "intraprovinciais" (envolvendo contratantes moradores em localidades paulistas distintas daquelas onde se fizeram os registros) e "interprovinciais" (envolvendo contratantes residentes em outras províncias do Império). Não podemos descartar a possibilidade de esse critério, em alguns casos, implicar aventarmos movimentações de cativos diferentes das que efetivamente ocorreram. Contudo, não cremos que tais casos - os quais, se existentes, decerto abrangeram uma minoria das pessoas negociadas - comprometam os resultados de nossa análise. 
da tentativa de burlar a legislação. Mesmo porque a penalidade por essa burla não ia além da declarada nulidade do negócio.

Assim, por exemplo, em um artigo anterior, sobre duas localidades situadas noVale do Paraíba paulista, Guaratinguetá e Silveiras, ao longo da década de 1870, ao voltarmos nossa atenção para o informe do preço de acordo com as idades, apontamos já para esse efeito diferenciado acarretado pela libertação dos nascituros:

[...] a elevação dos preços [entre dez. 1872-nov. 1874 e jan. 1878-dez. 1879] havida no caso dos cativos com idades de 10 a 14 anos (84,3\% para os homens e $41,2 \%$ para as mulheres) supera as calculadas entre os escravos de 15 a 24 anos (25,2\% para ambos os sexos) e de 25 a 34 anos (31,0\% para homens e $25,8 \%$ para mulheres). É possível que, sob o efeito da Lei do Ventre Livre, de 1871, tenham-se valorizado de maneira mais que proporcional exatamente aqueles cativos, em especial os do sexo masculino, cuja expectativa de vida em cativeiro fosse mais longa. Afinal, ainda que a eficácia dessa lei para a efetiva libertação dos nascituros seja discutível, e a utilização dos "serviços" dos ingênuos uma prerrogativa dos seus "proprietários" - de fato, proprietários de suas mães -, é evidente que a reposição da mão de obra escrava não se daria mais nos mesmos moldes que antes. (Motta; Marcondes, 2000, p. 280) ${ }^{15}$

A transação registrada em Piracicaba, aos 16 de outubro de 1875, é outra a ilustrar a comercialização desses meninos. Uma firma, Martins \& Irmãos, sediada no município de Grão-Mogol, na Província de Minas Gerais, vendeu para os irmãos Jayme e Ricardo P. Almeida, moradores em Piracicaba, os seguintes escravos: José (12 anos), Olegário (10),Vi-

15 Para Areias, outra localidade vale-paraibana paulista, desta feita computando intervalos temporais antes e após a Lei doVentre Livre, esse comentário foi corroborado: "Os preços médios reais dos rapazes [de 10 a 14 anos de idade] experimentaram um incremento de 59,4\% dos anos de 1860 para os de 1870 , de Rs. $863 \$ 632$ para Rs. 1:377\$001, ao passo que os das moças sofreram uma diminuição de 11,1\%, de Rs. 1:085\$274 para Rs. 964\$571. Tais variações, é claro, devem ser ponderadas pelo fato de serem poucos os preços individuais coletados para a faixa etária em questão [...]. Não obstante, a depreciação das mulheres, em decorrência da 'extinção' do ventre gerador de escravos, bem como a valorização mais que proporcional dos cativos homens com menos idade, para os quais era mais longa a expectativa da vida em cativeiro, colocam-se como resultados esperados da vigência da lei de setembro de 1871" (Motta, 2012a, p. 185-186). 
cente (13) e Isidoro (12). A referida pessoa jurídica atuou com a procuração dos escravistas, todos igualmente residentes em Grão-Mogol. Casemiro Francisco Baptista era senhor de Isidoro; José de Quadros Mello, deVicente; José e Olegário pertenciam ao Barão de Grão-Mogol ${ }^{16}$. Três desses quatro moleques, os que estão arrolados no Quadro 1, têm idades que deveriam impedir sua venda, se ela implicasse a separação de seus pais. Nenhum comentário sobre essa questão foi adicionado ao documento.

Duas outras crianças nascidas em distintas províncias do Império estão presentes no Quadro 1. Manoel, natural de Santa Catarina, comercializado num lote de seis escravos aos 20 de julho de 1874, e Simão, pernambucano, transacionado em 5 de outubro de 1880 num conjunto de oito cativos. Manoel, em que pese ter sido matriculado na província catarinense, em São José, estava sendo vendido por um morador em Piracicaba, Manoel Ferraz de Arruda Campos. Para as cinco pessoas restantes que integravam esse negócio, os senhores eram três, todos residentes em Santa Catarina, dos quais Arruda Campos era bastante procurador. Quem adquiriu o lote, Pedro Ferraz de Arruda Campos, era filho do vendedor/procurador, residente em Piracicaba como seu pai. Esses cinco escravos eram todos, como o menino Manoel, nascidos e matriculados em Santa Catarina; suas idades variavam de 4 a 50 anos, três eram do sexo masculino e havia um grupo familiar formado por uma mulher solteira, Luiza, de 28 anos, acompanhada por dois filhos, Firmino (7) e Rosalina (4) ${ }^{17}$. O valor pelo qual essa meia dúzia de pessoas foi transacionada igualou-se a Rs 3:950\$000.

16 Gualter Martins Pereira, primeiro e único Barão de Grão-Mogol, tempos depois, comprou a Fazenda Angélica, em Rio Claro, assim denominada por volta de 1850 em homenagem a Dona Maria Angélica, esposa do SenadorVergueiro, então detentor daquelas terras. O Barão "[...] acabou por vender suas terras em Minas Gerais, e adquiriu a Fazenda Angélica, juntamente com 300 cabeças de gado e 80 escravos (curiosamente, a maioria deles era proveniente da Bahia e de Minas Gerais), por 305:000\$000 (trezentos e cinco contos de réis). A escritura foi lavrada em 27 de agosto de 1881, no Cartório de Notas Thomaz Molina (atual $2^{\circ}$ Cartório de Notas de Rio Claro), livro 19, às páginas 34 a 36" (Benincasa; Bortolucci, 2009, p. 86).

17 Os dois inseridos na quinta coluna da Tabela 2. O proprietário dessa família era José Silveira de Souza Fagundes. Os outros vendedores que outorgaram procurações para Arruda Campos foram João Francisco Furtado e Felisberto José Corrêa, cada um deles se desfazendo de um cativo. 
Por seu turno, o garoto Simão foi comprado com 12 anos de idade por Dona Maria Joaquina de Barros. O lote adquirido por ela em outubro de 1880 tinha características bem distintas daquele no qual se inserira o catarinense Manoel. Eram oito cativos valiosos (o preço ajustado foi de Rs 19:200\$000 pelo conjunto), todos rapazes solteiros e indicados como aptos para o serviço da roça; além de Simão, os demais tinham idades entre 16 e 20 anos. Ele era o único natural de Pernambuco e fora matriculado no Recife. Sabino (20 anos) era da Parába, matriculado no município de Pilar. Luciano (16) e Dácio (18) eram baianos, matriculados, respectivamente, em Salvador e Camorim. Os demais eram todos cearenses: Manoel (20), Antonio (18), Manoel (18) e Francisco (18), matriculados nos municípios de Icó, São Bernardo, Imperatriz e novamente São Bernardo. O vendedor do lote, João Pereira de Almeida, residia em Campinas e foi representado no negócio por seu bastante procurador, Antonio Joaquim Soares Franco, morador em Piracicaba.

Três daqueles 14 pequenos cativos referidos no Quadro 1 eram naturais da província paulista: Lauro, João e Messias. Os dois primeiros faziam parte de um conjunto de 21 pessoas negociado em 7 de janeiro de 1875. Lauro, 12 anos, fora matriculado em Piracicaba; João, 11 anos, fora matriculado em Campinas. O lote, no valor de 34 contos de réis, foi vendido por Dona Maria Caetana Ferreira da Cunha para os irmãos Pedro e Francisco Augusto A. Barros, todos moradores em Piracicaba. As idades dos escravos variavam entre 4 e 57 anos, havia homens e mulheres, e foram identificados dois casais, um deles com três filhos ${ }^{18}$. Já Messias integrava um grupo de 25 escravos vendido em 31 de dezembro de 1878. Os contratantes eram Joaquim Fernando Paes de Barros, o vendedor, residente na localidade paulista de Capivari, e José Fernando de Almeida Barros, o comprador, de Piracicaba. Havia vários casais entre essas 25 pessoas, mas nenhuma indicação de que o menino, de 12 anos, fosse filho de algum deles.

Por fim, o caso de Vicente encerra a lista de crianças do Quadro 1. Com 11 anos de idade, ele foi negociado aos 17 de dezembro de 1879. Em sua descrição, o menino pardo é dito "sem pais". Ao que tudo indica, Vicente, bem como os demais 46 escravos - homens e mulheres de

18 Duas dessas crianças com idades inferiores a 13 anos, portanto incluídas na quinta coluna da Tabela 2 . 
idades variadas, entre eles várias famílias - que foram vendidos juntamente com ele, além dos muitos ingênuos relacionados com suas mães, poderiam não sofrer nenhum deslocamento por conta da venda. $O$ que estava sendo alterado, em duas transações paralelas, era o proprietário, tanto dos escravos como da fazenda em que eles viviam. O vendedor, José Rodrigues Caldeira, lavrador de Piracicaba, com seus bens hipotecados ao Banco do Brasil, estava repassando tudo ao capitalista Arsênio Corrêa Galvão, residente no próximo município de Itu.Vale a pena transcrevermos um excerto da escritura concernente a essa venda de 47 cativos:

[...] escravos estes empregados na cultura da fazenda Boa Esperança, neste Município, e que estão hipotecados com a mesma ao Banco do Brasil por escritura passada a vinte de novembro de mil oitocentos e setenta e sete nas Notas do Tabelião Sayão Lobato Sobrinho e ao Comendador Joaquim Gomes de Alvim e Moisés Gomes Travassos por escritura de vinte e um de novembro do mesmo ano e nas Notas do mesmo Tabelião, vende os mencionados quarenta e sete escravos, assim onerados, ao segundo contratante Arsênio Corrêa Galvão pelo preço de oitenta contos de réis assumindo o comprador todas as responsabilidades contraídas pelo vendedor pelas mencionadas escrituras de hipotecas [...]. Os oitenta contos de réis preço destes escravos, bem como os cinquenta contos de réis preço por que vendeu hoje ao mesmo comprador a fazenda Boa Esperança serão pagos com a exoneração da responsabilidade do vendedor pelas mencionadas hipotecas e o excesso dessas responsabilidades em dinheiro, tudo na forma e condições constantes da escritura firmada nas Notas deste Tabelião em data de hoje e pela qual vendeu ao mesmo comprador a fazenda Boa Esperança, obrigando-se a fazer sempre boa a presente venda.

\subsection{Vendas de crianças acompanhadas de familiares, presentes ou não outros escravos}

Se, como vimos na subseção anterior, foram 15 as crianças escravas com 12 ou menos anos de idade comercializadas desacompanhadas de familiares em Piracicaba, no período de 1874 a 1880, corresponderam ao triplo disso (46) aquelas transacionadas com seus pais e/ou mães, compusessem o negócio ou não outros cativos não aparentados. Com o intuito de analisarmos essas 46 crianças, retomamos a quarta e a quinta colunas da Tabela 2, cujos dados vão reproduzidos, respectivamente, na 
segunda e na quarta colunas da Tabela 3. Adicionalmente, essa última tabela fornece a distribuição dos ingênuos presentes (terceira e quinta colunas da Tabela 3), irmãos menores dos pequenos escravos, de cujos serviços passariam a usufruir os contratantes compradores de seus irmãos e pais e/ou mães.

Tabela 3 - Escravos com 12 ou menos anos transacionados "em família" e eventuais irmãos ingênuos, segundo presença ou não de outros cativos e de acordo com o ano do registro. (Piracicaba, 1874-1880)

\begin{tabular}{|c|c|c|c|c|c|}
\hline Anos & $\begin{array}{c}\text { FAMILIARES } \\
\text { PRESENTES } \\
\text { (A) } \\
\end{array}$ & $\begin{array}{c}\text { IRMÃOS } \\
\text { INGÊNUOS EM } \\
\text { (A) }\end{array}$ & $\begin{array}{c}\text { FAMILIARES E } \\
\text { NÃO FAMILIARES } \\
\text { PRESENTES (B) }\end{array}$ & $\begin{array}{c}\text { IRMÃOS } \\
\text { INGÊNUOS EM } \\
\text { (B) }\end{array}$ & TotaIs \\
\hline 1874 & 4 & 2 & 2 & - & 8 \\
\hline 1875 & 7 & 2 & 4 & - & 13 \\
\hline 1876 & 5 & 2 & 1 & - & 8 \\
\hline 1877 & - & - & 1 & 1 & 2 \\
\hline 1878 & 3 & 4 & 8 & 6 & 21 \\
\hline 1879 & 2 & 5 & 7 & 5 & 19 \\
\hline 1880 & - & - & 2 & 2 & 4 \\
\hline Totais & 21 & 15 & 25 & 14 & 75 \\
\hline
\end{tabular}

Fonte: Escrituras de transações envolvendo escravos.

Foram 21 as crianças cativas negociadas com familiares, $e$ apenas com familiares, e com elas trocaram de senhor 15 irmãos nascidos após a Lei de setembro de 1871. De outra parte, foram 25 as crianças escravas transacionadas com familiares, mas também com outros cativos, e com elas foram envolvidos nos negócios 14 irmãos mais jovens, ingênuos. Lembremos que a maioria quase absoluta das crianças vendidas desacom panhadas de familiares (14 das 15) eram do sexo masculino. Como seria o esperado, nas transações "em família”, a distribuição das crianças segundo o sexo apresentou-se bem mais equilibrada. Dos 46 casos, os meninos somaram $25(54,3 \%)$ e as meninas 21 (45,7\%). Decerto o equilíbrio seria ainda maior se estivéssemos computando a totalidade dos filhos gerados nas famílias em questão; todavia, alguns, ainda que incluídos nos negócios, tinham mais de 12 anos; outros, por serem maiores de 12 anos, podem não ter sido negociados; alguns, talvez muitos, teriam já falecido; e, finalmente, não computamos os ingênuos nessa distribuição por sexo, pois não foi possível, na maior parte dos casos, identificarmos se eram meninos ou meninas. 
Cabe observarmos que esses ingênuos com irmãos escravos com 12 ou menos anos de idade corresponderam a quase exatamente metade (29) do total de 59 beneficiários da Lei do Ventre Livre mencionados nas escrituras consideradas neste artigo ${ }^{19}$. Como podemos perceber com base na Tabela 4, nos três últimos anos do período cresceu a quantidade de ingênuos em geral, bem como a dos dois segmentos destacados. No triênio 1878-1880 foram identificados 22 (75,9\%) dos 29 ingênuos com irmãos escravos de 12 ou menos anos de idade; e $25(83,3 \%)$ dos 30 ingênuos sem irmãos escravos naquela faixa etária. Eis outro resultado esperado. Afinal, como decorrência da legislação servil, a partir de fins de 1883 não existiriam mais crianças cativas com menos de 13 anos e a esse resultado chegar-se-ia gradualmente com a passagem do tempo.

Tabela 4 - Crianças ingênuas transacionadas segundo presença de irmãos escravos com 12 ou menos anos de idade e de acordo com o ano do registro. (Piracicaba, 1874-1880)

\begin{tabular}{c|c|c|c}
\hline ANOS & $\begin{array}{c}\text { COM IRMÃOS ESCRAVOS } \\
\text { COM 12 OU MENOS ANOS }\end{array}$ & $\begin{array}{c}\text { SEM IRMÃOS ESCRAVOS } \\
\text { COM 12 OU MENOS ANOS }\end{array}$ & TotaIs \\
\hline 1874 & 2 & 2 & 4 \\
1875 & 2 & 3 & 5 \\
1876 & 2 & - & 2 \\
1877 & 1 & - & 1 \\
1878 & 10 & 8 & 18 \\
1879 & 10 & 11 & 21 \\
1880 & 2 & 30 & 8 \\
Totais & 29 & & 59 \\
\hline
\end{tabular}

Fonte: Escrituras de transações envolvendo escravos.

No Quadro 2 apresentamos alguns informes acerca dos 21 pequenos cativos transacionados com familiares e apenas com estes, ou seja, aqueles que compuseram a segunda coluna da Tabela 3 . Transcrevemos seus nomes, dos quais inferimos o sexo, e idades, os nomes e idades de seus pais e/ou mães, e, quando presentes, os nomes e idades de seus irmãos maiores de 12 anos. Além disso, indicamos a quantidade de irmãos ingênuos eventualmente referidos no documento e a data do registro das escrituras.

19 Conforme a quarta coluna da Tabela 1, que corresponde à coluna "Totais" da Tabela 4. Os 30 ingênuos sem irmãos escravos com 12 ou menos anos comporão o último dos contingentes objeto de nossa análise, ao fim da presente subseção do texto. 


\begin{tabular}{|c|c|c|c|c|}
\hline \multicolumn{5}{|c|}{$\begin{array}{l}\text { Quadro } 2 \text { - Escravos com } 12 \text { ou menos anos transacionados apenas com familiares. } \\
\text { Identificação e idades desses familiares, quando informadas. (Piracicaba, 1874-1880) }\end{array}$} \\
\hline $\begin{array}{l}\text { Nome DA CRIANÇA } \\
\text { (IDADE) }\end{array}$ & $\begin{array}{l}\text { PAI E/OU MÃE } \\
\text { (IDADES) }\end{array}$ & $\begin{array}{c}\text { IRMÃOS ESCRAVOS } \\
\text { (IDADES) }\end{array}$ & IRMÃOS INGÊNUOS & $\begin{array}{c}\text { DATA DA } \\
\text { ESCRITURA }\end{array}$ \\
\hline Joaquina (7) & Maria (26) & - & 1 & $11 / 7 / 1874$ \\
\hline Júlia (10) & Benedita (52) & - & - & $5 / 9 / 1874$ \\
\hline $\begin{array}{l}\text { Bartholomeu (6) } \\
\text { e Francisco (4) }\end{array}$ & $\begin{array}{l}\text { Roque (37) } \\
\text { e Isabel (23) }\end{array}$ & - & 1 & $7 / 12 / 1874$ \\
\hline Joana (5) & $\begin{array}{l}\text { Tobias (28) } \\
\text { e Juliana (28) }\end{array}$ & - & 1 & $3 / 2 / 1875$ \\
\hline Julião (10) & Ursulina (25) & Caetano (13) & 1 & $6 / 8 / 1875$ \\
\hline $\begin{array}{l}\text { Maria (7), } \\
\text { Firmino (5), } \\
\text { José (4), } \\
\text { Joaquim (11) } \\
\text { e Faustino (10) }\end{array}$ & Ignez (38) & - & - & $23 / 11 / 1875$ \\
\hline Ladislau (8) & $\begin{array}{l}\text { Lourenço (45) } \\
\text { eVerônica (38) }\end{array}$ & - & - & $29 / 4 / 1876$ \\
\hline $\begin{array}{l}\text { Ozória (9) } \\
\text { e Altevina (6) }\end{array}$ & Juliana (34) & $\begin{array}{l}\text { Autha (15) } \\
\text { e Geraldina (14) }\end{array}$ & 2 & $17 / 6 / 1876$ \\
\hline $\begin{array}{l}\text { Manoel (10) } \\
\text { e Irênio (4) }\end{array}$ & Justina (30) & - & - & $8 / 7 / 1876$ \\
\hline João (8) & Balbina (30) & - & 1 & $20 / 5 / 1878$ \\
\hline $\begin{array}{l}\text { Joanna (11) } \\
\text { e João (9) }\end{array}$ & Margarida (29) & - & 3 & $11 / 12 / 1878$ \\
\hline Vicente (8) & Pureza (29) & - & 2 & $2 / 1 / 1879$ \\
\hline Sebastião (9) & $\begin{array}{l}\text { Amaro (57) } \\
\text { e Esméria (32) }\end{array}$ & $\begin{array}{l}\text { Pulchéria (14) } \\
\text { e Luis (15) }\end{array}$ & 3 & $2 / 6 / 1879$ \\
\hline
\end{tabular}

Fonte: Escrituras de transações envolvendo escravos.

Cinco dessas 21 crianças foram vendidas com seus pai $e$ mãe. Foram quatro casais, e para apenas um deles o grupo familiar negociado se limitava a pai, mãe e um filho com menos de 13 anos: Lourenço, Verônica e o pequeno Ladislau, vendidos em 29 de abril de 1876. Os três haviam sido matriculados no município paulista de Itapeva da Faxina, onde morava o vendedor, o Alferes Joaquim José de Macedo, que concretizou o negócio por intermédio de um procurador. Joana, em fevereiro de 1875 , foi vendida com seus pais, Tobias e Juliana, e a essa mulher de 28 anos acompanhou também uma criança ingênua. Da mesma forma, um ingênuo acompanhava o casal Roque e Isabel, ven- 
didos em dezembro de 1874 com seus filhos, Bartholomeu e Francisco, ambos escravos.

O último dos casais listado no Quadro 2 correspondeu à mais numerosa das unidades familiares lá consideradas. O negócio foi realizado aos 2 de junho de 1879 e envolveu o menino Sebastião, de 9 anos de idade. Com ele foram vendidos os pais, o já idoso Amaro $^{20}$ e sua mulher Esméria, os irmãos mais velhos, Pulchéria e Luis, cativos tal como Sebastião, e transferidos os direitos de usufruto dos serviços de três irmãos menores, nascidos após a Lei doVentre Livre. Portanto, oito pessoas: pai, mãe e meia dúzia de filhos. Não obstante Amaro e Esméria sejam descritos como casados, os três filhos cativos, vale dizer, os mais velhos, eram ditos filhos naturais. De fato, consta do manuscrito a informação de que Esméria era solteira quando da matrícula. A união, pois, foi legalizada apenas depois de vários anos de convívio ${ }^{21}$. Amaro era africano e o restante da família era natural de São Paulo; todos haviam sido matriculados em Piracicaba, município onde residiam ambos os contratantes da transação.

As demais crianças escravas com 12 ou menos anos arroladas no Quadro 2 foram negociadas com apenas um de seus genitores, em todos os casos a mãe. Foram nove essas mulheres, seis delas (66,7\%), solteiras: Maria, Benedita, Juliana, Justina, Balbina e Pureza. Dentre essas mães solteiras, cabe destacar Juliana, de 34 anos de idade, vendida com quatro filhas escravas, duas maiores de 12 anos, Autha e Geraldina, e duas menores, Ozória e Altevina, além de acompanhada por dois filhos ingênuos.

20 Em artigo anterior expusemos as razões que nos levam a fazer "[...] nossa opção pelo cômputo, como cativos idosos, daqueles com idades iguais ou superiores a 50 anos. Esse procedimento, de resto, parece coadunar-se com inferências extraídas da legislação e de anúncios de jornais da segunda metade do Oitocentos, reveladores dos interesses dos próprios escravistas" (Motta, 2010, p. 49).

21 Uma situação, de resto, em alguma medida recorrente em nossa sociedade escravista. Por exemplo, Robert Slenes, analisando dados disponíveis para Campinas, Província de São Paulo, escreveu: “[...] o mais provável é que reflitam uma tendência, especialmente presente nos plantéis pequenos, de muitas mulheres terem o primeiro filho quando ainda solteiras, casando-se pela Igreja só algum tempo depois. Felizmente, há informações que nos permitem seguir estas mulheres no tempo, e assim confirmar esta conclusão" (Slenes, 1987, p. 219). Esméria, por conseguinte, ilustraria de maneira mais extremada essa tendência, uma vez que os três mais velhos dentre seus filhos mencionados na escritura haviam nascido com ela ainda solteira. 
Registrada em 17 de junho de 1876, foi essa venda também um negócio de âmbito local: comprador, o Doutor Felipe Xavier da Rocha, e vendedor, o Comendador Francisco José da Conceição, residiam em Piracicaba, ainda que este último tenha sido representado por seu procurador, Doutor João Baptista da Rocha Conceição ${ }^{22}$.

Os casos de duas outras dessas mães solteiras, Balbina e Maria, justificam comentários adicionais. A primeira, com 30 anos, foi vendida aos 20 de maio de 1878 com seu filho João (8), sendo a dita escrava acompanhada pelo ingênuo Eusébio, de cerca de 1 ano de idade. Balbina era natural de Itapetininga e João de São Sebastião do Paranapanema, ambas localidades paulistas. $\mathrm{O}$ vendedor apresentou ao Tabelião o documento da Coletoria de Paranapanema com os dados da matrícula de mãe e filho, documento que lhe é devolvido "por conter a matrícula de mais dois outros escravos filhos da mesma Balbina". É, pois, bastante plausível supormos que esses dois outros filhos já estivessem com idades superiores aos 12 anos, com o que seria legitimada a separação da mãe, o que não ocorria nem com João nem com o ingênuo Eusébio.

A venda de Maria foi efetivada por José Gomes da Silva em 11 de julho de $1874^{23}$. A escrava tinha 26 anos de idade e era acompanhada de sua filha, Joaquina, também cativa, de 7 anos. O comprador, José Emygdio da Silva Novais, por elas pagou dois contos de réis e recebeu, junto com Maria, o ingênuo Benedito, com "um ano e meio mais ou menos". Todavia, havia ainda outra criança, João, nascido escravo e contando 5 anos de idade em julho de 1874, cujo destino é descrito na escritura da venda que o separava de sua mãe e irmãos:

Disse mais o vendedor que por esta venda fica a escrava Maria separada do filho João, de cinco anos de idade, que continua em poder dele vendedor, por ter-lhe sido deixado em testamento, por sua finada mãe, para servi-lo durante sua vida e depois ficar livre, por que em beneficio da liberdade podem ser separados do pai e da mãe os filhos menores de doze anos que forem manumitidos com a cláusula de futuros serviços, segundo dispõe o artigo noventa, parágrafo primeiro, segunda parte do Regulamento número cinco mil cento e trinta e cinco de três de Novembro de mil oi-

22 Os sobrenomes de comprador, vendedor e procurador do comprador indiciam a possibilidade da existência de relações familiares entre os três.

23 Fizemos já referência a esse negócio em trabalho anterior (cf. Motta, 2012b, p. 21). 
tocentos e setenta e dois, e por serem intransferíveis os serviços daquele menor, artigo noventa e um do mesmo Regulamento.

Vemos aí uma possibilidade aberta pelo "Regulamento da Lei do Ventre Livre", aprovado pelo Decreto referido, de contrariar a legislação proibitiva da separação entre mães e seus filhos de 12 ou menos anos. Vale a pena transcrevermos o $\mathbb{S} 1^{\circ}$ do Artigo 90 do Decreto n. 5.135, que começa reafirmando a dita legislação, tanto no que respeita ao Decreto n. 1.695, de setembro de $1869^{24}$, quanto ao $\$$ 7oㅡ do Artigo 4은 da Lei n. 2.040, de setembro de 1871:

Art. 90.A Lei $\mathrm{n}^{\circ} .1 .695$ de 15 de setembro de 1869 permanece em seu inteiro vigor, com as seguintes alterações:

$\$ 1^{\circ}$. Em qualquer caso de alienação ou transmissão de escravos é proibido, sob pena de nulidade, separar os cônjuges, e os filhos menores de 12 anos do pai ou mãe. (Lei $-\operatorname{art.} 4^{\circ}$. $\ 7^{\circ}$.)

Esta disposição compreende a alienação ou transmissão extrajudicial.

Em benefício da liberdade, porém, podem ser separados do pai ou da mãe os filhos menores de 12 anos, que forem manumitidos com ou sem a cláusula de futuros serviços. (Coleção de leis do Império do Brasil, grifo nosso) ${ }^{25}$

Além das seis mães solteiras listadas no Quadro 2, havia duas viúvas, Ursulina (25 anos) e Margarida (29), e uma casada, Ignez (38). Ursulina era mãe de Caetano (13), Julião (10) e uma criança ingênua. Margarida foi vendida com seus filhos Joanna (11) e João (9), além de três ingênuos. E Ignez foi transacionada com cinco filhos, todos escravos e com idades entre 4 e 11 anos. A escritura, porém, não traz qualquer informação acerca do marido dessa cativa (escravo de outro senhor, livre, liberto, fugido etc.).É possível que a falta desse informe relacione-se ao fato de as mercadorias negociadas serem "partes ideais" daquelas pessoas. Martinho Morato da Conceição vendeu a metade que possuía na escrava Ignez e em seus cinco filhos para seu tio, o Comendador Francisco José

24 Ver a nota 9 acima.

25 É o seguinte o teor do Artigo 91 do "Regulamento da Lei doVentre Livre", também lembrado pelo vendedor de Maria para justificar a separação do pequeno João: "São intransferíveis os serviços, quer dos menores livres [...], quer os manumitidos gratuitamente com a cláusula de prestação dos mesmos serviços. Poderão, porém, ser alugados" (Coleção de leis do Império do Brasil). 
da Conceição, este último representado por seu bastante procurador e filho, Doutor João Baptista da Rocha Conceição ${ }^{26}$.Vale dizer, é possível que a família escrava em questão, aí incluído o não mencionado marido/ pai, já estivesse vivendo na escravaria do Comendador.

No Quadro 3 apresentamos as crianças escravas com 12 ou menos anos de idade negociadas com familiares (pai e/ou mãe, irmãos cativos com 13 ou mais anos e irmãos menores ingênuos) e com outros escravos. Enquanto a média de escravos negociados por escritura atingiu apenas 3,3 nos casos limitados a famílias (Quadro 2, 43 cativos em 13 escrituras), essa média elevou-se para 15,1 nas transações que envolveram igualmente escravos não aparentados (Quadro 3,181 cativos em 12 escrituras). Esse maior número de pessoas deu margem a que fosse possível identificar vários negócios envolvendo mais de um grupo familiar integrado por crianças com 12 ou menos anos de idade. Havia duas famílias presentes entre os 22 escravos negociados em 13 de setembro de 1875, bem como entre os 25 transacionados em 30 de março e entre os nove vendidos em 26 de dezembro de 1878. E foram quatro os grupos familiares identificados entre as 47 pessoas às quais se referiu a escritura registrada aos 17 de dezembro de 1879 .

Comparado ao Quadro 2, inserimos no Quadro 3 uma coluna adicional com o informe da quantidade dessas pessoas transacionadas além de cada uma das famílias descritas. Uma distinção significativa entre os dois conjuntos de famílias arrolados nos dois quadros é a participação relativa de situações nas quais os pequenos cativos foram vendidos juntamente com seus pai $e$ mãe. Dessa forma, estavam inseridas em famílias nucleares apenas cinco $(23,8 \%)$ das 21 crianças listadas no Quadro 2, ao passo que esse número elevou-se para $18(72 \%)$ das 25 elencadas no Quadro 3.

26 Martinho era menor, o que exigiu um alvará do Juiz de Órfãos autorizando a venda, bem como condicionou a forma de quitação informada ao Tabelião pelo procurador do comprador, Doutor João Baptista, “" [...] ficando seu constituinte obrigado a pagar a referida quantia de três contos de réis ao vendedor quando completar ele idade de vinte e um anos, com o prêmio que correrá desde já de nove por cento ao mês capitalizando anualmente até a final liquidação". Considerando que diversos estudos apresentam para a década de 1870 taxas de juros vigentes entre $9 \%$ e $18 \%$ ao ano, percebemos que a taxa de juros a ser paga pelo Comendador era deveras elevada, caracterizando um negócio "em família", de tio para sobrinho! Ver, por exemplo, Saes (1986, p. 68) e Marcondes (2002, p. 155-156). 


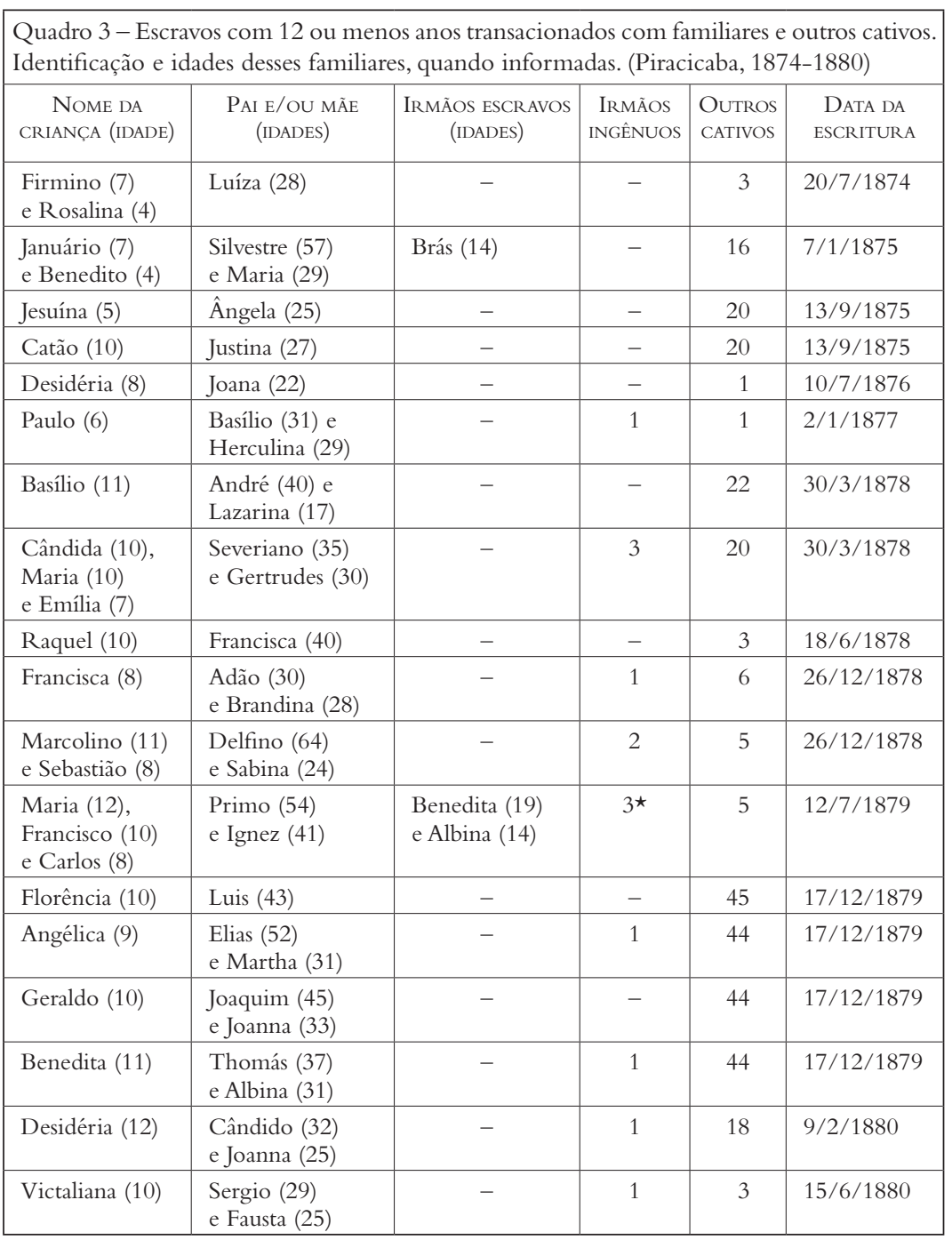

^ Dois desses ingênuos são filhos de Ignez; o terceiro é seu neto, filho de Benedita, portanto sobrinho de Maria, Francisco e Carlos.

Fonte: Escrituras de transações envolvendo escravos.

É possível que a maior proporção de casais vincule-se à maior importância relativa dos negócios de âmbito local ${ }^{27}$. Assim, das 21 crianças

27 As fontes primárias por nós compulsadas para a elaboração deste artigo, regra geral, 
do Quadro 2, 11 (52,4\%) foram vendidas localmente. Esse porcentual atingiu 72\% (18 em 25) para as crianças do Quadro 3. Reforçando a vinculação sugerida, notamos que dois dos quatro casais presentes no Quadro 2, assim como 11 dos 12 presentes no Quadro 3, foram transacionados entre contratantes que residiam em Piracicaba ${ }^{28}$.

A maior das transações contempladas no Quadro 3 foi a registrada em 17 de dezembro de 1879 e já a descrevemos na subseção anterior por conta da presença, entre os 47 escravos então vendidos, do menino Vicente, de 11 anos, "sem pais". Três casais com sua prole compunham a escravaria da Fazenda Boa Esperança, objeto desse negócio: Elias (52 anos) e Martha (31), pais de Angélica (9); Joaquim (45) e Joanna (33), pais de Geraldo (10); e Thomás (37) e Albina (31), pais de Benedita (11). Martha e Albina eram, cada uma delas, também acompanhadas por um filho ingênuo. A outra criança cativa com 12 ou menos anos identificada nesse conjunto de pessoas, Florência (10), foi listada com seu pai, Luis (43), este descrito como solteiro.

E o menor lote de cativos mencionado no Quadro 3 foi o transacionado em 10 de julho de 1876. Joana, solteira com 22 anos de idade, foi vendida com sua filha Desidéria, de 8 anos. Compunha o conjunto a escrava Victória, de 18 anos, solteira. Quem vendia Victória era Dona Francisca da Cruz Prates, moradora em Caetité, na Bahia, ao passo que Joana e Desidéria eram vendidas pelo mineiro de Montes Claros, Francisco Xavier Affonso Pereira. Francisca e Francisco eram representados pelo mesmo procurador, Clemente de Quadros Bittencourt. Jayme e

não nos permitiram conhecer o tamanho das escravarias em que passariam a viver as pessoas negociadas, tampouco o tamanho das escravarias nas quais elas viviam anteriormente à efetivação dos negócios objeto de nossa atenção. Entretanto, tendo em vista a verificação, bastante recorrente nos estudos sobre o tema das famílias escravas - ver, entre muitos, Slenes (2011) e Motta (1999) -, de que as maiores escravarias poderiam conformar ambientes mais propícios à formação e ampliação de unidades familiares entre seus integrantes, não podemos deixar de apontar a possível influência dessa variável (o tamanho das escravarias envolvidas), além do âmbito das transações (locais o não), na explicação ao menos parcial da diferença descrita entre os resultados fornecidos nos Quadros 2 e 3.

28 As crianças na faixa etária em tela, identificadas em transações que extrapolavam o âmbito local, mas se restringiram ao território da Província de São Paulo, corresponderam a 33,3\% das que compõem o Quadro 2, e a apenas 8\% das listadas no Quadro 3. Os porcentuais correlatos, nos casos relativos a negócios interprovinciais, igualaram-se, respectivamente, a $14,3 \%$ e a $20 \%$. 
Ricardo P.Almeida, de Piracicaba, irmãos e sócios, eram os compradores. As escravas eram naturais das mesmas províncias de seus senhores e haviam sido matriculadas nos mesmos municípios nos quais eles residiam.

Destaquemos também a mais numerosa dentre as famílias apontadas no Quadro 3, abarcando três gerações. Ela era formada por dez pessoas, sete escravos e três ingênuos. Outros cinco cativos completavam o conjunto de 12 escravos comercializados em 12 de julho de 1879. Naquele dia, compareceram perante o Tabelião em Piracicaba os contratantes Antonio Bento de Camargo, vendedor, e Inocêncio de Paula Eduardo, comprador, ambos moradores naquele município. O lote de 12 cativos foi vendido por Rs 14:900\$000. Com a exceção de Primo, africano com 54 anos de idade, todos os demais eram naturais da província paulista; e igualmente todos, agora com a inclusão de Primo, haviam sido matriculados em Piracicaba. A esposa do velho africano era Ignez, de 41 anos, e os filhos escravos do casal eram Benedita (19), Albina (14), Maria (12), Francisco (10) e Carlos (8). Ignez era acompanhada por dois filhos ingênuos, e um outro ingênuo era filho de Benedita, solteira, a filha presente mais velha de Ignez.

Esse negócio registrado em 12 de julho de 1879 ilustra o último dos segmentos de crianças menores de 12 anos de que nos ocupamos neste artigo: os 30 ingênuos que não possuíam irmãos escravos naquela faixa etária (distribuídos, segundo ano de registro da escritura, na terceira coluna da Tabela 4 acima). De fato, além da numerosa família encabeçada por Primo e Ignez, o conjunto negociado por Antonio Bento e Inocêncio era formado também pelo casal Bento (32 anos) e Francisca (27). Embora eles não fossem acompanhados por nenhum filho escravo, eram três as crianças por eles geradas na vigência da Lei n. 2.040, as quais eram a partir daquela data repassadas do vendedor para o comprador, antigo e novo detentores do direito aos serviços daquelas crianças na forma da lei.

Além de Bento e Francisca, outros nove casais, ao longo do período 1874-1880, e em especial no triênio 1878-1880, foram negociados com filhos apenas ingênuos. Desses nove casais, três possuíam três filhos, quatro possuíam dois filhos e dois eram pais de apenas uma criança ingênua. Um décimo primeiro casal, com três filhos ingênuos, possuía também um filho escravo, porém com mais de 12 anos e, por conseguinte, não inserido nos Quadros 2 ou 3. O conjunto de 30 crianças 
ingênuas completa-se com quatro casos de mulheres solteiras e um de mulher viúva, cada uma delas acompanhada de um ingênuo.

\section{Considerações finais}

No período analisado neste artigo, de 1874 a 1880, Piracicaba possuía pouco menos de 20 mil habitantes, contingente no qual os escravos não atingiam os três décimos. Era um município dedicado principalmente à agricultura, sendo importante a lavoura de cana, porém apresentando maior destaque a cafeicultura. De fato, foram anos de grande expansão da produção cafeeira no Império brasileiro, expansão imbricada a uma nítida intensificação no ritmo do comércio interno de cativos. Os "municípios cafeeiros" sobressaíram-se então como pontos de chegada daquele tráfico.

Nossa atenção voltou-se ao segmento das crianças com 12 ou menos anos de idade, fossem elas escravas, comercializadas conforme escrituras registradas em Piracicaba, fossem elas ingênuas, mencionadas na mesma documentação e acompanhando, em obediência à legislação vigente, suas mães e eventualmente outros familiares sujeitos ao cativeiro e, por conseguinte, objeto das negociações ajustadas entre seus compradores e vendedores. Foram 61 crianças escravas e 59 ingênuos na faixa etária contemplada. Somados, esses 120 infantes corresponderam a cerca de um quinto do total de 616 pessoas transacionadas - ou com o direito ao usufruto de seus serviços transferido, no caso dos libertos pela Lei do Ventre Livre - nas escrituras que compulsamos.

Evidentemente, os negócios de compra e venda da mercadoria humana estão entre as melhores ilustrações da violência inerente ao cativeiro. Tais negócios possuíram sempre um elevado potencial de desorganização, em maior ou menor grau, da vida dos escravos. A comercialização de crianças cativas com 12 ou menos anos, desacompanhadas de familiares, poderia decerto representar um extremo dessa violência e desorganização, houvesse ou não outras pessoas integrando os lotes transacionados. Vimos que foram 15 as crianças que trocaram de senhores nessa condição, aproximadamente um quarto dos 61 escravos negociados. Dessas 15, apenas em duas situações as informações explicitadas na escritura poderiam servir de justificativa para a aparente 
inobservância dos dispositivos legais. Em uma delas, Sebastiana, de 11 anos, "é filha de Antonia, hoje liberta"; na outra,Vicente, também com 11 anos de idade, "sem pais", foi vendido com todos os demais escravos da Fazenda Boa Esperança, bem como a própria fazenda, para um novo proprietário.

Por conseguinte, 13 cativos com 12 ou menos anos de idade foram negociados desacompanhados de familiares e sem qualquer menção a motivos, a exemplo de uma pretensa orfandade, que evidenciassem não estarem essas crianças sendo separadas de seus pai e/ou mãe por conta das aludidas vendas. Percebemos a concentração desses casos no início do período analisado. Talvez esse fato indicie certa defasagem temporal em termos da efetiva aplicação da letra da lei. De outra parte, a verificação do desequilíbrio absoluto no que respeita ao sexo daqueles infantes - eram 13 meninos - permite vislumbrarmos que, da perspectiva dos escravistas, teria havido perfeita e rápida compreensão dos efeitos da libertação dos nascituros. Afinal, por que não comprar e vender esses moleques apesar da lei, se o risco fosse tão somente a eventual declaração de nulidade do negócio efetivado? Contudo, se assim era, por que foram apenas 13? Seria plausível sugerirmos a existência de riscos não explicitados, cuja possibilidade de identificação, no horizonte dos estudiosos, cresce na medida em que seja por eles atribuído maior peso a um protagonismo escravo em meio àquela sociedade escravista.

As crianças na faixa etária por nós selecionada, comercializadas com familiares, somaram 46. Em 21 desses casos, essas famílias compunham a totalidade dos lotes negociados, e em 25 foram transacionadas também pessoas não aparentadas. E foram 29 os ingênuos, irmãos mais novos desses 46 infantes, nascidos na vigência da Lei doVentre Livre.Tenhamos claro que a presença de grupos familiares não garante que as famílias tenham sido completamente preservadas. Não à toa, foram poucas as situações envolvendo mais de duas gerações de famílias escravas. Vale dizer, as vendas de cativos "em família" de modo algum depõem contra a violência do cativeiro. Não obstante, tais vendas podem muito bem ser encaradas, ultrapassando a ótica do atendimento exclusivo do interesse dos escravistas, a partir da perspectiva privilegiada no feliz comentário crítico de Ciro Cardoso, manifesto em sua análise do tema da brecha camponesa; crítica esta decorrente do "[...] fato de muitos autores não tratarem as sociedades escravistas como verdadeiras sociedades, e 
sim como uma espécie de campo de concentração generalizado" (Cardoso, 1987, p. 59).

Do conjunto de negócios por nós tratado neste artigo, convém destacar novamente, nestas considerações finais, aquele realizado em 12 de julho de 1879 e que envolveu três gerações de uma família escrava. O casal Primo e Ignez, respectivamente, com 54 e 41 anos de idade, transacionado com cinco filhos escravos, Benedita (19 anos), Albina (15), Maria (12), Francisco (10) e Carlos (8), havendo outras três crianças ingênuas acompanhando a família, duas delas filhas de Ignez, e a outra filha de Benedita. Cabe observar a inexistência de óbices legais a que Benedita e seu pequeno, bem como Albina, fossem separadas do restante da família.Todavia, não o foram. Inocêncio de Paula Eduardo os comprou a todos, além de mais cinco escravos, entre os quais outro casal, Bento e Francisca, sem filhos cativos e com três crianças ingênuas, de Antonio Bento de Camargo.

Comparados às vendas de crianças com parentes e não parentes, os negócios envolvendo pequenos escravos com 12 ou menos anos nos quais foram transacionadas apenas pessoas aparentadas abrangiam, em média, um número menor de cativos, e neles foi também significativamente menor a participação de casos nos quais tanto o pai como a mãe dos infantes estavam presentes. Ao que parece, a maior frequência de famílias nucleares acompanhava o predomínio de transações realizadas no âmbito local, ajustadas, portanto, entre contratantes residentes, tanto compradores como vendedores, em Piracicaba. Talvez fosse possível conjecturarmos que o tráfico envolvendo longos deslocamentos dos escravos tornasse mais fácil o encobrimento de eventuais inobservâncias dos dispositivos legais.

Em suma, apresentamos algumas reflexões acerca das características do comércio interno de crianças com 12 ou menos anos de idade, na forma como ele se apresentou em Piracicaba, São Paulo, no período de maior intensidade daquele tráfico, uma etapa concomitante ao movimento de expansão cafeeira paulista em sua trajetória em direção ao oeste da província. 


\section{Fontes}

\section{Livros especiais para transações envolvendo escravos (termos de abertura)}

CONSTITUIÇÃO - "Servirá este livro com cento e cinquenta folhas para nele o segundo Tabelião Joaquim de Oliveira (ilegível) lavrar as escrituras de vendas de escravos (ilegível) Art. $3^{\circ}$. S $1^{\circ}$. do Dec. nº 2.699 de 28 de novembro de 1860, além dos que são exigidos pelas (ilegível) em geral. Leva no fim o encerramento. Constituição, 28 de outubro de 1866. O Juiz Municipal. Manoel Avelino de Andrade."

CONSTITUIÇÃO - "Servirá este livro pertencente ao Tabelião César para o lançamento das escrituras de vendas de escravos. Todas as folhas do livro irão por mim numeradas e rubricadas com a rubrica de meu uso, que é a seguinte: (ilegível) e pelo Termo de Encerramento se (ilegível) de suas folhas. Constituição, 14 de dezembro de 1874. O Juiz Municipal. Antonio José (ilegível) (ilegível)."

PIRACICABA - "Servirá este livro para serem lançadas as escrituras de compra e venda de escravos, passadas pelo $2^{\circ}$. Tabelião. Contém 46 folhas todas por mim numeradas e rubricadas com a rubrica que uso - C. Saraiva. Piracicaba, 22 de maio de 1878. Canuto José Saraiva."

PIRACICABA - "Servirá este livro para nele serem lançadas as escrituras de compra e venda de escravos, passadas no Cartório do $2^{\circ}$. Tabelião Francisco Pimenta Gomes. Será por mim rubricado em todas as suas folhas, cujo número será declarado no termo de encerramento, com a rubrica que uso - C. Saraiva. Piracicaba, 20 de outubro de 1879. O Juiz Municipal. Canuto José Saraiva."

\section{Referências bibliográficas}

BASSANEZI, Maria Sílvia Casagrande Beozzo (org.). São Paulo do passado: dados demográficos. Campinas: NEPO-UNICAMP, 1998, 1 CD-ROM.

BENINCASA, Vladimir; BORTOLUCCI, Maria Ângela Pereira de Castro e Silva. Fazenda Angélica e o Barão de Grão-Mogol. Labor \& Engenho, v. 3, n. 1, p. 82-109, 2009.

CARDOSO, Ciro Flamarion S. Escravo ou camponês? O protocampesinato negro nas Américas. São Paulo: Brasiliense, 1987.

COLEÇÃO de leis do Império do Brasil, 1808-1889. Disponível em <http://www2. camara.gov.br/legislacao/publicacoes/doimperio>. Acesso em 19/12/2014.

DEAN, Warren. Rio Claro: um sistema brasileiro de grande lavoura, 1820-1920. Rio de Janeiro: Paz e Terra, 1977.

EISENBERG, Peter. Modernização sem mudança: a indústria açucareira em Pernambuco, 1840-1910. Rio de Janeiro/Campinas: Paz e Terra/Universidade Estadual de Campinas, 1977. 
GORENDER, Jacob. O escravismo colonial. 4. ed. rev. e ampl. São Paulo: Ática, 1985.

LOBATO, Monteiro. Cidades mortas. 24. ed. São Paulo: Brasiliense, 1986.

LUNÉ, Antonio José Baptista de; FONSECA, Paulo Delfino da (orgs.). Almanak da Província de São Paulo para 1873. Ed. fac-sim. São Paulo: Imprensa Oficial do Estado - IMESP/Arquivo do Estado de São Paulo, 1985.

MARCONDES, Renato Leite. O financiamento hipotecário da cafeicultura no Vale do Paraíba paulista (1865-87). Revista Brasileira de Economia, v. 56, n. 1, p. 147-170, jan.-mar. 2002.

MARQUES, Manuel Eufrásio de Azevedo. Apontamentos históricos, geográficos, biográficos, estatísticos e noticiosos da Província de São Paulo, seguidos da cronologia dos acontecimentos mais notáveis desde a fundação da Capitania de São Vicente até o ano de 1876. São Paulo: Comissão do IV Centenário da Cidade de São Paulo, 1953, 2 v.

MELLO, Zélia Maria Cardoso de. Metamorfoses da riqueza: São Paulo, 1845-1895. Contribuição ao estudo da passagem da economia mercantil-escravista à economia exportadora capitalista. São Paulo: HUCITEC/Prefeitura do Município de São Paulo, 1985.

MILLIET, Sergio. Roteiro do café e outros ensaios: contribuição para o estudo de história econômica e social do Brasil. São Paulo: s.ed., 1939.

MOTTA, José Flávio. Corpos escravos, vontades livres: posse de cativos e família escrava em Bananal (1801-1829). São Paulo: FAPESP/Annablume, 1999.

MOTTA, José Flávio. O tráfico de escravos velhos (Província de São Paulo, 1861-1887). História. Questões e Debates, ano 27, n. 52, p. 37-69, jan.-jun. 2010.

MOTTA, José Flávio. Escravos daqui, dali e de mais além: o tráfico interno de cativos na expansão cafeeira paulista (Areias, Guaratinguetá, Constituição/Piracicaba e Casa Branca, 1861-1887). São Paulo: Alameda/FAPESP, 2012a.

MOTTA, José Flávio. A lei, ora a lei! Driblando a legislação no tráfico interno de escravos no Brasil (1861-1887). História e Economia Revista Interdisciplinar, v. 10, n. 1, p. $15-28,1^{\circ}$ semestre $2012 \mathrm{~b}$.

MOTTA, José Flávio; MAR CONDES, Renato Leite. O comércio de escravos no Vale do Paraíba paulista: Guaratinguetá e Silveiras na década de 1870. Estudos Econômicos, v. 30, n. 2, p. 267-299, abr.-jun. 2000.

PETRONE, Maria Thereza Schorer. A lavoura canavieira em São Paulo. Expansão e declínio (1765-1851). São Paulo: DIFEL, 1968.

PRADO JR., Caio. Formação do Brasil contemporâneo: colônia. São Paulo: Companhia das Letras, 2011.

SAES, Flávio Azevedo Marques de. Crédito e bancos no desenvolvimento da economia paulista, 1850-1930. São Paulo: IPE-USP, 1986.

SLENES, Robert Wayne. Escravidão e família: padrões de casamento e estabilidade familiar numa comunidade escrava (Campinas, século XIX). Estudos Econômicos, v. 17, n. 2, p 217-227, maio-ago. 1987.

SLENES, Robert Wayne. Na senzala, uma flor: esperanças e recordações na formação da família escrava - Brasil Sudeste, século XIX. 2. ed. corrigida. Campinas: Editora da UNICAMP, 2011. 
TORRES, Maria Celestina Teixeira Mendes. Um lavrador paulista do tempo do Império. Separata da Revista do Arquivo Municipal. São Paulo, Divisão do Arquivo Histórico, Prefeitura do Município de São Paulo, n. CLXXII, 1966.

ZALUAR, Augusto Emílio. Peregrinação pela Província de São Paulo (1860-1861). Belo Horizonte/São Paulo: Itatiaia/EDUSP, 1975. 